\title{
RESTRICTION ENDONUCLEASE ANALYSIS OF THE GENOMES OF DIFFERENT ISOLATES OF CHICKEN ANEMIA VIRUS AMPLIFIED BY POLYMERASE CHAIN REACTION
}

\author{
S.M.Z.H. Chowdhury ${ }^{1 *}$, A.R. Omar ${ }^{2}$, A. Ideris ${ }^{2}$, H. Bejo ${ }^{2}$ and A.A. Jamaluddin ${ }^{3}$ \\ ${ }^{1}$ Livestock Division, Bangladesh Agricultural Research Council, Farmgate, Dhaka-1215, Bangladesh \\ ${ }^{2}$ Faculty of Veterinary Medicine, University Putra Malaysia, 43400 UPM Serdang, Selangor, Malaysia \\ ${ }^{3}$ Veterinary Research Institute, 59, Jalan Sultan Azlan Shah, 31400 Ipoh, Perak, Malaysia
}

\begin{abstract}
Four DNA fragments (fragments $A, B, C$ and $D$ ) covering the whole genome of chicken anemia virus (CAV) were amplified enzymatically by polymerase chain reaction (PCR) using four pairs of oligonucleotide primers. The DNA fragments were amplified from each of nine CAV isolates including eight Malaysian isolates and one European isolate (Cux-1). For all nine CAV isolates, fragment A (1518 bp) was digested with one restriction enzyme, Eco130l (Styl); fragment B (926 bp) with three enzymes, Eco130l (Styl), Hpall and Mbol separately; fragment C (675 bp) with also three enzymes, BsuRI (HaellI), Hinfl, and Hpall separately; and the fragment D (552 bp) with one enzyme, EcoRI. Enzyme digested products of different fragments were separated by agarose gel or polyacrylamide gel electrophoresis. Each of the eightenzymatic reactions differentiated at least two isolates except the Hpall digestion of fragment $\mathrm{C}$ where no isolate was distinguished. The overall restriction endonuclease $(R E)$ analysis separated four isolates (BL-1, BL2 , BL-4 and BL-5) in one group and the rest five isolates (SMSC-1, SMSC-2, 3-1, BL-3 and Cux-1) were differentiated from each other and also from the group of four isolates, based on the number of restriction site differences and the fragments generated by different enzymatic digestions. The study revealed that RE analysis could be used to identify and differentiate CAV isolates based on the number of restriction site differences. The study showed that more isolates, even the isolates from the same poultry farm, could be differentiated with proper genomic diversity after RE analysis of more genome fragments compared to that of single genome fragment.
\end{abstract}

Keywords: Chicken anemia virus; polymerase chain reaction; restriction endonuclease analysis.

\footnotetext{
*Corresponding author e-mail: ziqrul06@yahoo.com
} 
S.M.Z.H. Chowdhury et al.

\section{INTRODUCTION}

Chicken anaemia virus (CAV) is an economically important avian pathogen with a worldwide distribution (AboElkhair et al., 2014; De Herdt et al., 2001; Farkas et al., 1998, Ganar et al., 2017; Ledesma et al., 2001; McNulty 1991; Olszewska-Tomczyk et al., 2016; Rehman et al., 2011; Stanislawek and Howell, 1994; Zhou et al., 1996). The virus causes aplastic anaemia and generalised lymphoid atrophy with a concomitant immune suppression characterised by secondary bacterial, viral infections or vaccination failures (Adair, 2000; Bülow et al., 1983; Engstrom and Luthman 1984; Rosenberger and Cloud 1989; Schat, 2003). The mortality is usually between $5 \%$ and $10 \%$, but up to $60 \%$ has been recorded (Coombes and Crawford 1996; McNulty 1991). The virus is small, non-enveloped, spherical, 23 to $26 \mathrm{~nm}$ in diameter, containing a circular single-stranded DNA genome of $2.3 \mathrm{~kb}$ (Coombes and Crawford 1996; Li and Cui, 2007; McNulty 1991; Noteborn et al., 1991; Pope 1991; Zhang et al., 2012).

CAV is a member of genus Gyrovirus in the family Anelloviridae (Breitbart, 2015). The CAV isolates originating from different parts of the world belong to the same serotype and produce the same pathogenic effects in experimentally inoculated chicks (McNulty 1991). Later a study proposed a possible second serotype (Spackman, et al., 2002a,b). However, studies have been carried out to characterize the virus based on its DNA sequence (Noteborn et al., 1992; Todd et al., 1992; Tham and Stanislawek, 1992). Both Southern analysis and restriction mapping showed only minor differences on the CAV genomes of the field isolates from United States (Noteborn et al., 1992). However, Todd et al. (1992) differentiated CAV isolates by restriction endonuclease (RE) analysis of PCR-amplified DNA. They used three enzymes (HaeIII, HinfI, and HpaII) for digestion of only one 675 bp PCR-amplified fragment from different CAV genomes. Genetic variations of different CAV isolates were also detected by other workers using RE analysis of PCR-amplified CAV genome fragments (Oluwayelu et al., 2005; Nayabian and Mardani, 2013; van Santen et al., 2001). Both type specific and common DNA sequences can be detected among various CAV isolates. However, analysis of more genome fragments with different restriction enzymes can differentiate different CAV isolates more appropriately than that of single genome fragment and this information could be important in epidemiological point of view. In this paper, we investigated for the first time the molecular differences of the genomes of different CAV isolates by restriction endonuclease analysis of PCR-amplified DNA fragments covering the whole CAV genome.

\section{MATERIALS AND METHODS}

\section{Viruses}

Five CAV isolates, BL-1, BL-2, BL-3, BL-4, and BL-5, isolated recently at University Putra Malaysia (UPM); three CAV isolates, SMSC-1, SMSC-2 and 3-1, isolated at Veterinary Research Institute (VRI), Malaysia, and an European CAV 
isolate Cux-1, kindly provided by Dr. K.A. Schat, College of Veterinary Medicine, Cornell University, Ithaca, NY, USA, were used for the study.

\section{Cells and cell culture}

MDCC-MSB1 cells, a cell line derived from a Marek's disease lymphoma, were kindly provided by the Director, VRI, Ipoh, Perak, Malaysia. The cell culture was maintained following the methods described by Chowdhury et al. (2002). For each isolate, two $\mathrm{ml}$ of the stock virus were inoculated into $2 \times 10^{6}$ cells in a $75-\mathrm{cm} 2$ flask containing $18 \mathrm{ml}$ RPMI 1640 media. One flask was also maintained as an uninoculated control. The infected and control cells were harvested 48-72 hours after infection.

\section{DNA extraction}

DNA was extracted from uninfected and CAV infected MDCC-MSB1cells harvested at 48-72 hours post infection following the procedures described by Chowdhury et al. (2002) with minor modification and stored at $-20^{\circ} \mathrm{C}$ until use.

\section{Amplification of DNA fragments by polymerase chain reaction (PCR)}

The following DNA fragments were amplified by PCR from the whole genome of CAV for analysis by restriction endonulease enzymes (Figure 1a). The nucleotide (nt) positions used here are based on Cux-1 sequence (Noteborn et al., 1991).

(i) Fragment A: 1518 bp fragment (nt 2317-1515). Two oligonucleotide primers flanking fragment A were as follows. Forward primer (CAV5): 5'- ATC GAA TTC CGA GTG GTT ACT ATT CC -3' (nt 2317-23) and the reverse primer (CAV6): 5'- GAA GGA TCC CTC ATT CTT AGT GGC -3' (nt 1515-1492) (Soiné et al., 1993).

(ii) Fragment B: 926 bp fragment (nt 1463-69). The primers flanking fragment B were as follows. Forward primer (CAV 9): 5'- GAC ACA TTG AAA CCC GCT TT $-3^{\prime}$ (nt 1463-1482) and the reverse primer (CAV 10): 5'- GCG ATT CGT CCA TCT TGA CT -3' (nt 69-50) (Todd et al., 1996).

(iii) Fragment C:675 bp fragment (nt 844-1519). The primers flanking fragment $C$ were as follows. Forward primer (CAV 13): 5'- GAC TGT AAG ATG GCA AGA CGA GCT C -3' (nt 844-868) and the reverse primer (CAV 14): 5' - GGC TGA AGG ATC CCT CAT TC -3' (nt 1519-1500) (Todd et al., 1992).

(iv) Fragment D: 552 bp fragment (nt 2074-306). The primers designed based on Cux-1 sequence (Noteborn et al., 1991), were used for amplifying fragment D. Forward primer (CAV15): 5'- GTA ATG AAG AGC GAT GCA TGG GC- 3' (nt 2074-2096) and the reverse primer (CAV6b): 5'- CCA TTT TCG AAA CGT CAC TTT CGC- $3^{\prime}$ (nt 306-283). 


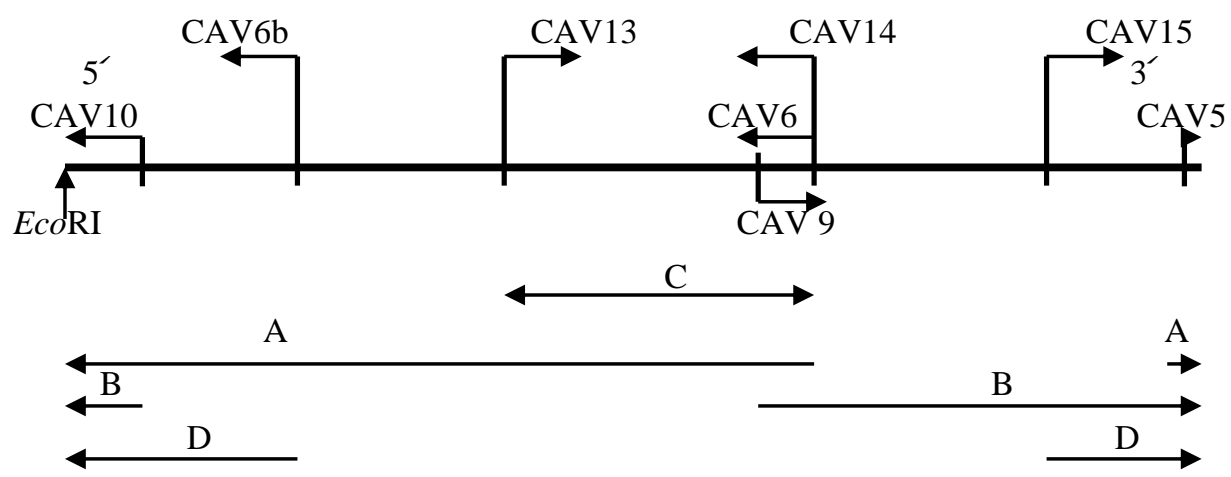

Figure 1a. Amplification strategy of different fragments from CAV genome (2319 bp) based on Cux-1 sequence (M55918). The circular CAV genome is represented by a straight line, whose both ends are connected.

The fragment $\mathrm{A}$ and fragment $\mathrm{B}$ covers the whole CAV genome. Fragment $\mathrm{C}$ falls within the fragment $\mathrm{A}$ at the $3^{\prime}$-end, and fragment $\mathrm{D}$ includes part of fragment $\mathrm{B}$ (at $3^{\prime}$-end) and part of fragment A (at $5^{\prime}$-end) (Figure 1a). All oligonucleotide primers were synthesized by Operon Technologies, Inc., USA. For amplification of all of the above fragments, PCR's were carried out in $50 \mu \mathrm{l}$ reaction mixture containing distilled water, PCR buffer $(1 \mathrm{x}), \mathrm{MgCl}_{2}(2.5 \mathrm{mM})$, dNTP mixture (0.3 $\mathrm{mM}$ each), forward and reverse primers (30 pmole each), Taq DNA polymerase (2.0 unit) and DNA template $(0.2$ to $0.5 \mu \mathrm{g})$. The thermal cycling profiles were as follows: initial 5 min incubation at $94^{\circ} \mathrm{C}$, followed by 40 cycles of $94^{\circ} \mathrm{C}$ for $1 \mathrm{~min}, 60^{\circ} \mathrm{C}$ for $1.5 \mathrm{~min}$, $72^{\circ} \mathrm{C}$ for $2 \mathrm{~min}$; a final incubation at $72^{\circ} \mathrm{C}$ for $10 \mathrm{~min}$ and cooling at $4^{\circ} \mathrm{C}$. The PCR products were run on 1 to $1.5 \%$ agarose gel electrophoresis. After staining with ethidium bromide, the specific bands were excised and purified by Geneclean kit (BIO 101, Inc., USA) following the supplied instructions.

\section{Analysis of amplified DNA fragments by restriction endonuclease enzymes}

For all nine isolates of CAV, the fragment A (1518 bp) was digested with one restriction enzyme, Eco130I (StyI); the fragment B (926 bp) with three enzymes, Eco130I (StyI), HpaII and MboI separately; the fragment C (675 bp) with three enzymes BsuRI (HaeIII), HinfI, and HpaII; and the fragment D (552 bp) with one enzyme, EcoRI. All enzymatic digestions were performed separately in a $20 \mu \mathrm{l}$ reaction mixture containing buffer (1x) for individual enzyme as recommended by the manufacturer (MBI Fermentas, Lithuania), enzyme (15-25 units), distilled water (if any) and the purified DNA fragment. The reaction mixture was incubated at $37^{\circ} \mathrm{C}$ for 10-14 hours.

\section{Agarose gel electrophoresis}

After incubation, the resulting digested products, in case of fragment A/StyI were run in $2 \%$ agarose gel electrophoresis and in case of fragment D/EcoRI were run in $2.5 \%$ 
agarose gel electrophoresis, and the gels were stained in ethidium bromide $\left(1 \mu \mathrm{g} \mathrm{ml}^{-}\right.$ $\left.{ }^{1}\right)$. For fragment A/StyI, $1 \mathrm{~kb}$ DNA ladder (MBI Fermentas, Lithuania) and for fragment D/EcoRI, 50 bp DNA ladder, ready to use (MBI Fermentas, Lithuania) was used as molecular size markers. The separated DNA fragments in the gel were visualised by using a UV transilluminator and photographs were taken.

\section{Sodium dodecyl sulphate polyacrylamide gel electrophesis (SDS-PAGE)}

The fragment B digested products with each of StyI, HpaII and MboI, and fragment C digested products with each of HaeIII, HinfI, and HpaII were separated by SDSPAGE. For the experiment, 12\% separating or resolving gel and 4\% stacking gel were prepared and electrophoresis was conducted at $44-48 \mathrm{~V}$ in a Mini-Protein ${ }^{\circledR}$ II Electrophoresis Cell (BIO-RAD, USA) following the instructions of the manufacturer. The run was maintained up to $1.5 \mathrm{~cm}$ from the bottom level, which took about 4 hours. Fragments generated by digesting the $\phi X 174$ DNA (replicative form) with HaeIII were used as size markers. After electrophoresis, the gel was stained with ethidium bromide $\left(1 \mu \mathrm{g} \mathrm{ml}^{-1}\right)$. The separated DNA bands in the gel were visualised by the UV transilluminator and photographs were taken.

\section{RESULTS}

\section{PCR amplification of different fragments}

Analysis by agarose gel electrophoresis indicated single DNA fragment in all sets of PCR reactions. The PCR with primers flanking fragments $\mathrm{A}, \mathrm{B}, \mathrm{C}$ and $\mathrm{D}$, generated expected DNA fragments of around $1500 \mathrm{bp}, 900 \mathrm{bp}, 700 \mathrm{bp}$ and $550 \mathrm{bp}$, respectively, for all nine isolates.

\section{Restriction endonuclease analysis}

A total of six restriction enzymes (EcoRI, HaeIII, HinfI, HpaII, MboI, and StyI) were used for analysis of different amplified fragment DNAs covering the whole CAV genome. The restriction sites found for all enzymes with regard to different PCR amplified fragments of different isolates are shown in table 1.

\section{Fragment A (1518 bp)}

Fragment A was treated with the restriction endonuclease, StyI. The restriction map with StyI for fragment A is shown in figure 1b. StyI cleaved the 1518 bp fragment A from Cux-1 DNA at only one site, producing two fragments, A1 (1071 bp) and A2 (447 bp) (Figure 1b). The CAV isolates, SMSC-2, 3-1, BL-1, BL-2, BL4 and BL-5 produce the same profiles as Cux-1. However, the fragment A from isolates SMSC-1 and BL-3 remained undigested indicating absence of StyI site. The StyI digested products of fragment A, separated by $2 \%$ agarose gel, for all the nine isolates are shown in figure 2 . 
Table 1. Restriction endonuclease analysis of different PCR-amplified DNAs specified by different CAV isolates

\begin{tabular}{|c|c|c|c|c|c|c|c|c|c|c|c|}
\hline \multirow[t]{2}{*}{ DNAs } & \multirow[t]{2}{*}{ Enzy-me } & \multirow[t]{2}{*}{ Site } & \multicolumn{9}{|c|}{ Isolates } \\
\hline & & & SMSC-1 & SMSC-2 & $3-1$ & BL-1 & BL-2 & BL-3 & BL-4 & BL-5 & Cux-1 \\
\hline Frag. A & StyI & 1 & - & + & + & + & + & - & + & + & + \\
\hline \multirow{10}{*}{ Frag. B } & \multirow[t]{2}{*}{ StyI } & 1 & + & - & + & - & - & + & - & - & + \\
\hline & & 2 & + & + & + & + & + & + & + & + & + \\
\hline & \multirow{5}{*}{ HpaII } & 1 & + & + & + & + & + & + & + & + & + \\
\hline & & 2 & - & + & + & + & + & - & + & + & + \\
\hline & & 3 & + & + & + & + & + & + & + & + & + \\
\hline & & 4 & + & + & + & + & + & + & + & + & + \\
\hline & & 5 & + & - & - & - & - & + & - & - & - \\
\hline & \multirow{3}{*}{ MboI } & 1 & + & + & + & + & + & + & + & + & + \\
\hline & & 2 & + & + & - & + & + & + & + & + & + \\
\hline & & 3 & + & - & + & + & + & + & + & + & + \\
\hline \multirow{13}{*}{ Frag. C } & \multirow{6}{*}{ HaeIII } & 1 & - & + & + & + & + & + & + & + & + \\
\hline & & 2 & + & + & + & + & + & + & + & + & + \\
\hline & & 3 & - & + & + & + & + & + & + & + & + \\
\hline & & 4 & + & + & + & + & + & + & + & + & + \\
\hline & & 5 & - & + & + & + & + & + & + & + & + \\
\hline & & 6 & - & - & + & - & - & - & - & - & - \\
\hline & \multirow{4}{*}{ HinfI } & 1 & + & + & + & + & + & + & + & + & + \\
\hline & & 2 & + & + & + & + & + & + & + & + & + \\
\hline & & 3 & + & + & + & + & + & + & + & + & + \\
\hline & & 4 & + & + & - & + & + & + & + & + & - \\
\hline & \multirow{3}{*}{ HpaII } & 1 & + & + & + & + & + & + & + & + & + \\
\hline & & 2 & + & + & + & + & + & + & + & + & + \\
\hline & & 3 & + & + & + & + & + & + & + & + & + \\
\hline Frag. D & EcoRI & 1 & - & - & + & - & - & - & - & - & + \\
\hline
\end{tabular}

' + ' indicates presence and '-' indicates absence of restriction site.

Frag. $=$ Fragment. 


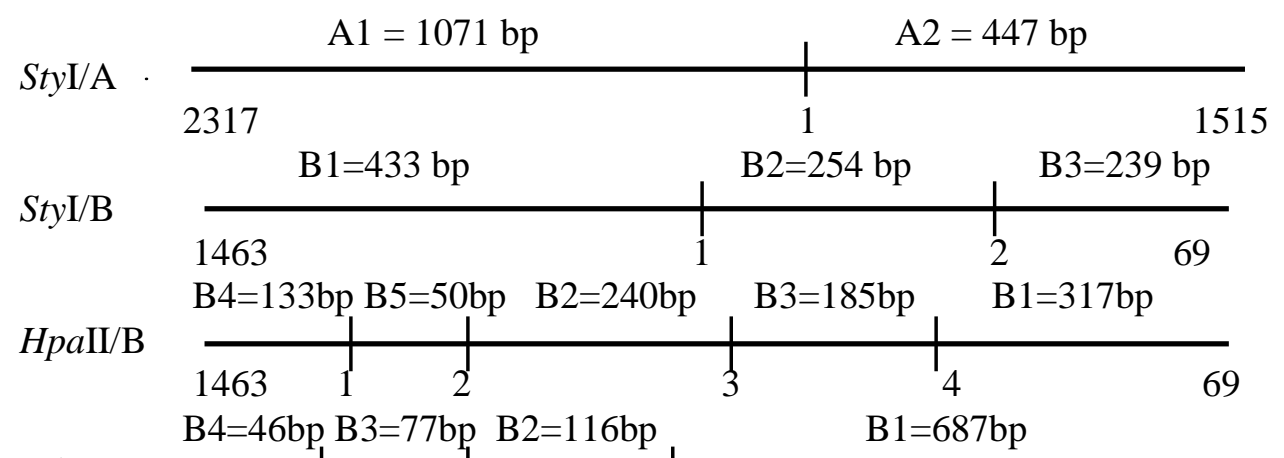

$M b o \mathrm{I} / \mathrm{B}$
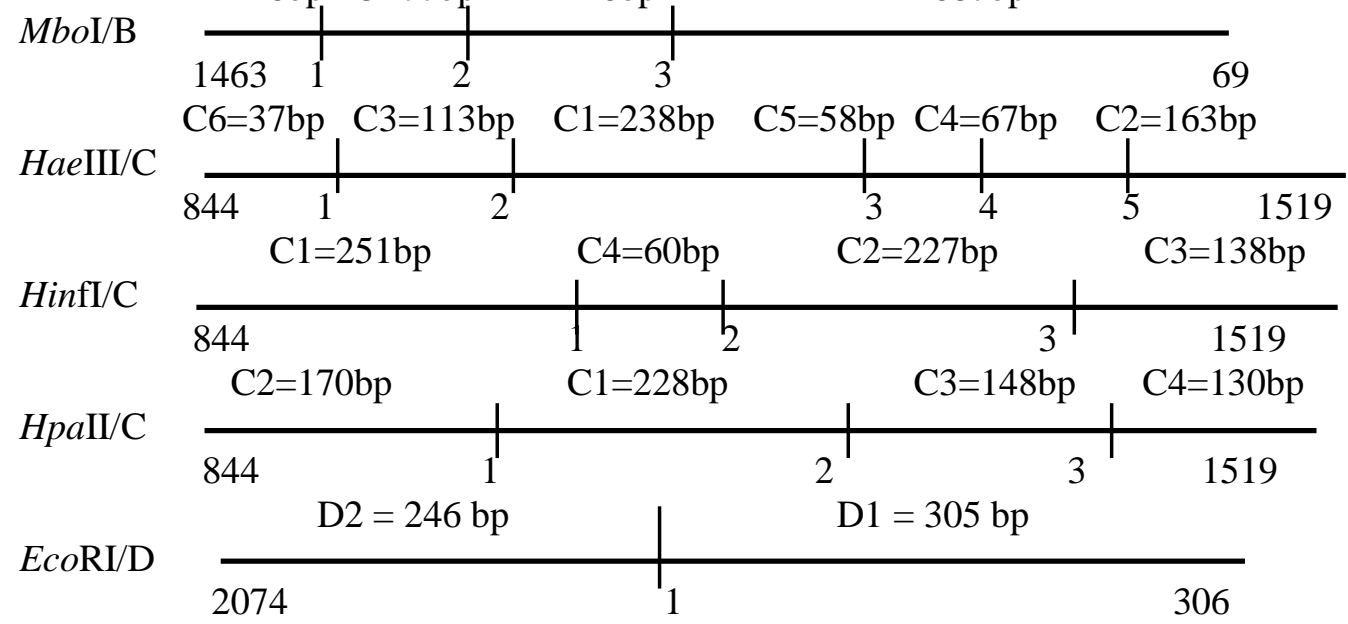

Figure 1b. Restriction map of different CAV fragments with respect to their enzyme(s). The position of restriction sites in the respective fragments and the internal fragment size (in bp) were predicted from the Cux-1 sequence (M55918).

\section{Fragment B (926 bp)}

Fragment B was treated with three restriction endonucleases, StyI, HpaII and MboI. The restriction maps with these enzymes for the fragment $B$ are depicted in figure $1 \mathrm{~b}$. The enzyme StyI cleaved the 926 bp fragment B from Cux-1 DNA at two sites producing three different fragments (433 bp, $254 \mathrm{bp}$ and $239 \mathrm{bp}$ ) (Figure 1b). Similar cleavage pattern were also found in SMSC-1, 3-1 and BL-3 isolates. On the other hand, the StyI site 1 was absent in the rest five isolates (SMSC-2, BL-1, BL-2, BL-4 and BL-5) leading to the generation of the fragment of $687 \mathrm{bp}$ and $239 \mathrm{bp}$ (calculated based on figure 1b, StyI/B) and absence of the fragments B1 (433 bp) and B2 (254 $\mathrm{bp})$. Electrophoresis in gels containing $12 \%$ acrylamide provided effective separation of the DNA fragments generated by StyI digestion of the fragment B (Figure 3, Styl/B). 


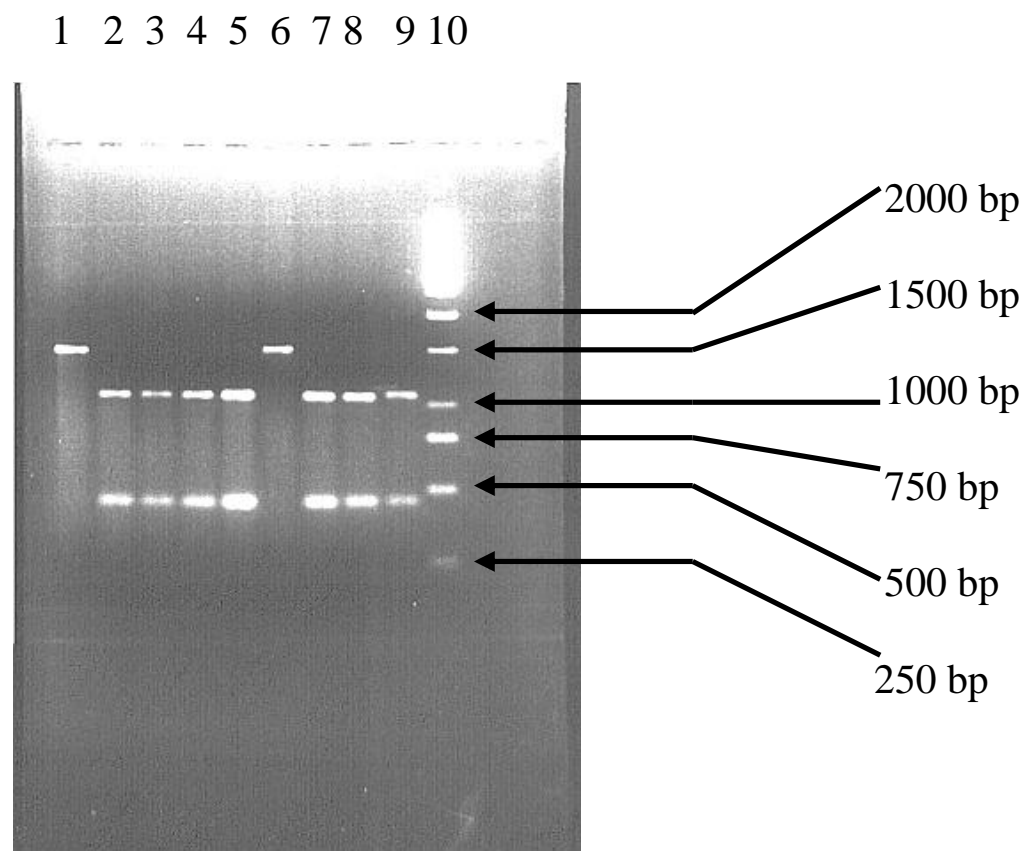

Figure 2. Restriction endonuclease (StyI) analysis of $1518 \mathrm{bp}$ fragment A amplified by PCR from DNAs specified by CAV isolates SMSC-1 (Lane 1), SMSC2 (Lane 2), 3-1 (Lane 3), BL-1 (Lane 4), BL-2 (Lane 5), BL-3 (Lane 6), BL-4 (Lane 7), BL-5 (Lane 8) and Cux-1 (Lane 9). Lane 10- $1 \mathrm{~kb}$ DNA size marker. Restriction fragments were separated by $2 \%$ agarose gel.

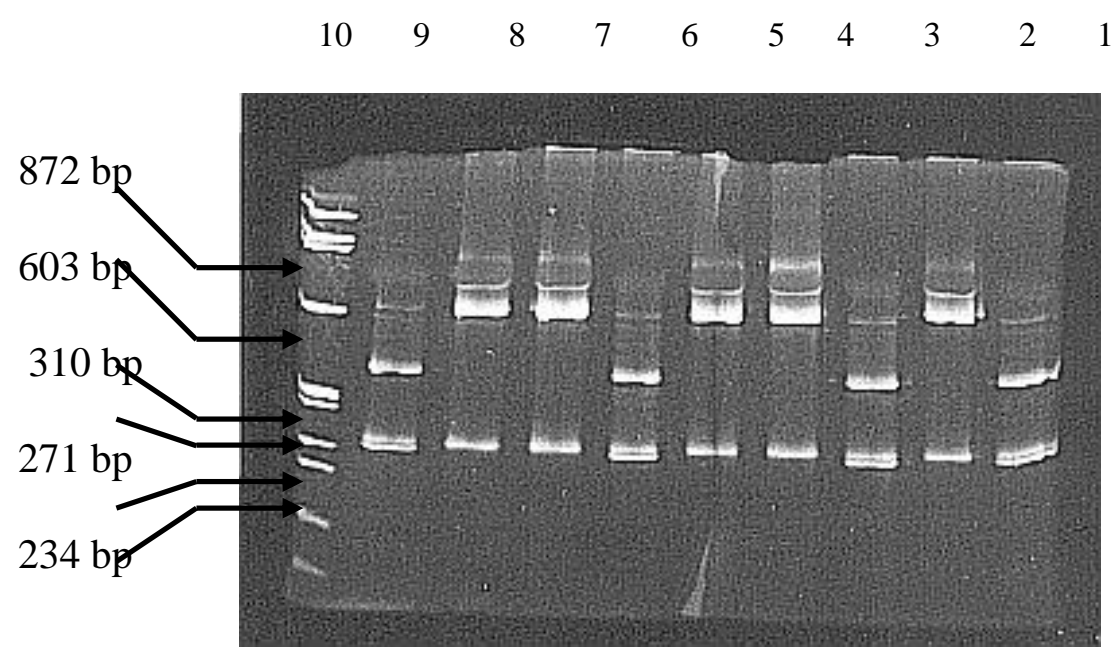



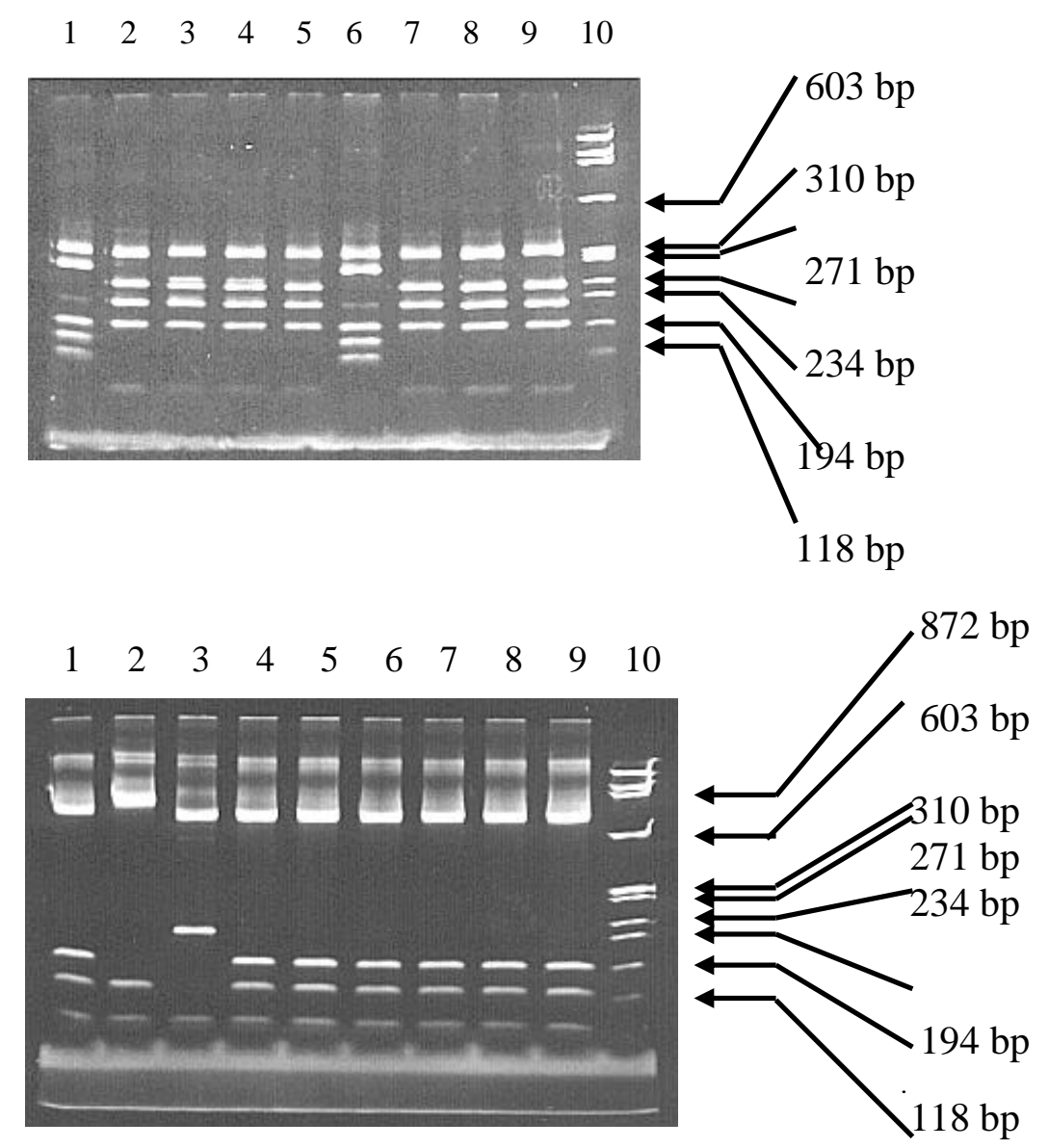

Figure 3: Restriction endonucleases (StyI, HpaII, MboI) analysis of 926 bp fragment B amplified by PCR from DNAs specified by CAV isolates SMSC-1 (Lane 1), SMSC-2 (Lane 2), 3-1 (Lane 3), BL-1 (Lane 4), BL-2 (Lane 5), BL-3 (Lane 6), BL-4 (Lane 7), BL-5 (Lane 8) and Cux-1 (Lane 9). Fragments generated by digesting the $\phi X 174$ DNA (replicative form) with HaeIII were used as size marker (Lane 10). Restriction fragments were separated by SDS-PAGE.

The enzyme HpaII cleaved fragment B from Cux-1 DNA at four sites generating five different DNA fragments of $317 \mathrm{bp}, 240 \mathrm{bp}, 185 \mathrm{bp}, 133 \mathrm{bp}$ and $50 \mathrm{bp}$ (Figure 1b). The fragment B of SMSC-2, 3-1, BL-1, BL-2, BL-4 and BL-5 isolates also showed similar pattern of fragments as Cux-1 after digestion with HpaII. The fragment $\mathrm{B}$ of SMSC-1 and BL-3 isolates, after digestion with HpaII also produced five fragments. Out of these five fragments, the pattern of the two fragments, B1 (317 bp) and B4 (133 bp), was similar to that of other seven isolates, but the pattern of the rest three 
fragments was different from that of other isolates. The site 2 was absent in SMSC-1 and BL-3 which leads to the creation of the fragment of $290 \mathrm{bp}$ (calculated based on figure 1b, HpaII/B) and absence of the fragments, B2 (240 bp) and B5 (50 bp). There was one additional site in fragment B3 (185 bp) of the SMSC-1 and BL-3 isolates, that led to the formation of two additional fragments below the fragment B4 (133 bp). The DNA fragments generated by HpaII digestion of fragment B were effectively separated by SDS-PAGE with $12 \%$ acrylamide (Figure 3, HpaII/B).

The enzyme $M b o$ I cleaved fragment B from Cux-1 DNA at three sites producing four different fragments, B1 (687 bp), B2 (116 bp), B3 (77 bp) and B4 (46 bp) (Figure 1b). The same pattern of fragments was also produced by digestion with MboI of the fragment B DNAs from SMSC-1, BL-1, BL-2, BL-3, BL-4 and BL-5 isolates. The difference was found in SMSC-2 and 3-1 isolates, both of which produced three fragments instead of four. In case of SMSC-2, the MboI site 3 was absent in fragment B that resulted in the absence of the fragments, B1 (687 bp) and B2 (116 bp). Instead, there was creation of an $803 \mathrm{bp}$ fragment (calculated on the basis of figure $1 \mathrm{~b}$, MboI/B). The other two fragments, B3 (77 bp) and B4 (46 bp), had the same pattern with Cux-1 and other isolates except 3-1 where only fragment B4 had the similarity. While in fragment B of 3-1, the $M b o$ I site 2 was absent that resulted in the generation of a $193 \mathrm{bp}$ fragment (calculated on the basis of figure $1 \mathrm{~b}, \mathrm{Mbol} / \mathrm{B}$ ) and absence of the fragments B2 (116 bp) and B3 (77 bp). The fragment B4 (46 bp) had similar pattern with all other isolates, and the fragment B1 $(687 \mathrm{bp})$ had also same pattern with other isolates except SMSC-2. The generated DNA fragments in case of all isolates were separated effectively by SDS-PAGE with $12 \%$ acrylamide. Figure 3 $(\mathrm{Mbo \textrm {I }} / \mathrm{B})$ displays the $\mathrm{Mbo \textrm {I }}$ digested products of fragment $\mathrm{B}$ for all isolates.

\section{Fragment C (675 bp)}

Fragment $\mathrm{C}$ was treated with three restriction endonucleases, HaeIII, HinfI and HpaII. The restriction map with HaeIII for fragment $\mathrm{C}$ is shown in figure $1 \mathrm{~b}$. HaeIII cleaved the 675 bp fragment $\mathrm{C}$ from Cux-1 DNA at five sites producing six different fragments. Other isolates, except SMSC-1 and 3-1, showed similar restriction profiles as Cux-1 after digestion of their fragment C DNAs with HaeIII. The enzyme digested fragment C DNA of SMSC-1 isolate producing only three fragments instead of six. The HaeIII sites 1, 3 and 5 were absent in fragment $\mathrm{C}$ of SMSC-1. The absence of site 1 led to the absence of fragments C3 (113 bp) and C6 (37 bp) and the formation of a $150 \mathrm{bp}$ fragment (calculated based on figure 1b, HaeIII/C). The absence of site 3 reflected with the creation of a $296 \mathrm{bp}$ fragment and absence of the fragments $\mathrm{C} 1$ (238 bp) and C5 (58 bp) (calculated based on figure 1b, HaeIII/C). While the absence of site 5 resulted in the deletion of fragments, C2 (163 bp) and C4 (67 bp) and the formation of a fragment of $230 \mathrm{bp}$ (calculated based on figure 1b, HaeIII/C). In case of 3-1, after HaeIII digestion of fragment C DNA, seven fragments were produced instead of six, out of which five fragments were seen in the gel. Here, all five HaeIII sites like Cux-1 and other six isolates were present, but there was an additional 
HaeIII site (site 6) in fragment $\mathrm{C} 4(67 \mathrm{bp})$ which was cleaved to produce a fragment that was merged with fragment $\mathrm{C} 5(58 \mathrm{bp})$ and a small fragment that was undetectable in the gel. Electrophoresis in gels containing $12 \%$ acrylamide provided effective separation of DNA fragments generated by HaeIII digestion of fragment $\mathrm{C}$ (Figure 4, HaeIII/C).
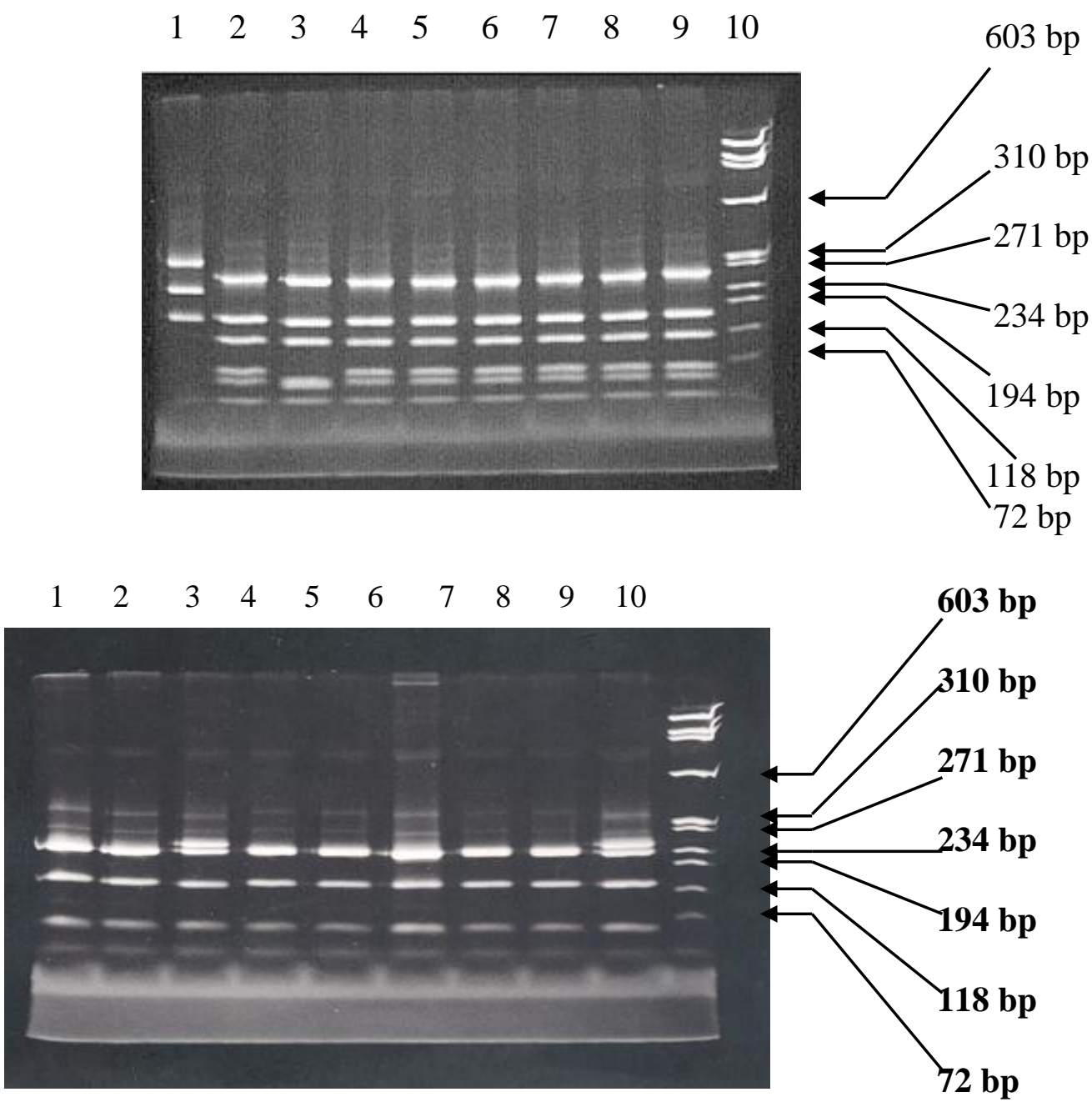
$\begin{array}{llllllllll}1 & 2 & 3 & 4 & 5 & 6 & 7 & 8 & 9 & 10\end{array}$

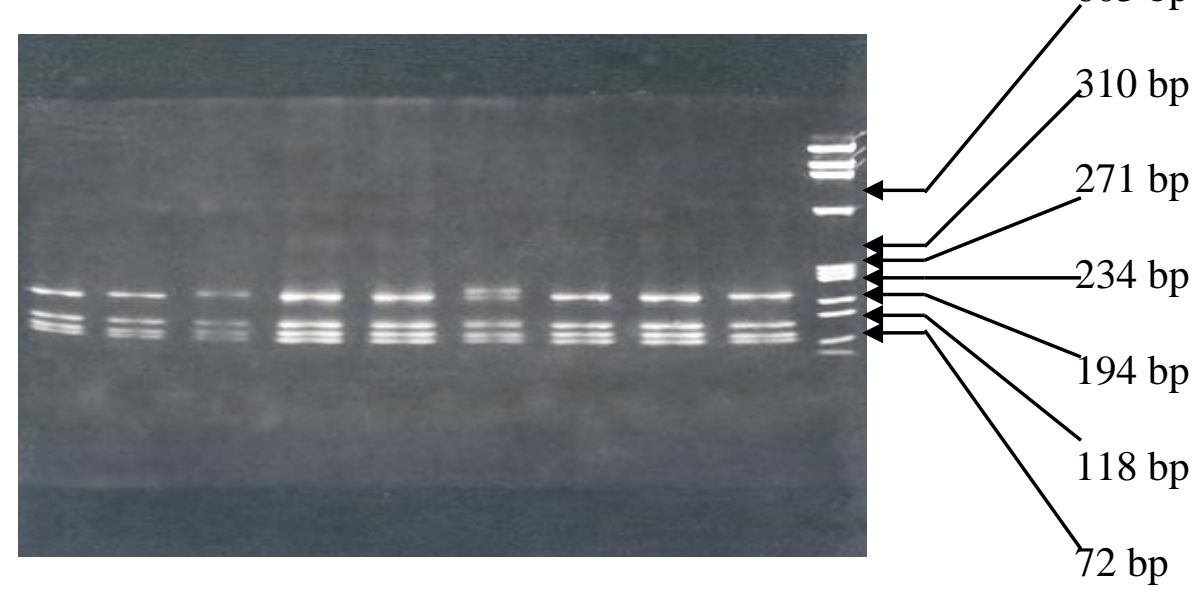

Figure 4: Restriction endonuclease (HaeIII, HinfI, HpaII ) analysis of 675 bp fragment $\mathrm{C}$ amplified by PCR from DNAs specified by CAV isolates SMSC-1 (Lane 1), SMSC-2 (Lane 2), 3-1 (Lane 3), BL-1 (Lane 4), BL-2 (Lane 5), BL-3 (Lane 6), BL-4 (Lane 7), BL-5 (Lane 8) and Cux-1 (Lane 9). Fragments generated by digesting the $\phi X 174$ DNA (replicative form) with HaeIII were used as size marker (Fermentas) (Lane 10). Restriction fragments were separated by SDS-PAGE.

HinfI cleaved fragment $\mathrm{C}$ from Cux-1 DNA at three sites producing four different fragments, C1 (251 bp), C2 (227 bp), C3 (138 bp) and C4 (60 bp) (Figure 1b). Similar profiles as Cux-1 was also showed by digestion with HinfI of the fragment $\mathrm{C}$ from 3-1 isolate. Whereas, other seven isolates exhibited a different profile producing five fragments, out of which three fragments were visible. There was one additional site in fragment $\mathrm{C} 1(251 \mathrm{bp})$ producing two fragments, of which the big one had almost the same mobility with fragment $\mathrm{C} 2$ (227 bp) showing a prominent band, the other one was so small that could not be visible in the acrylamide gel. The pattern for $\mathrm{C} 3$ and $\mathrm{C} 4$ fragments is similar to that in Cux-1 and 3-1 isolates. The HinfI digested products of fragment $\mathrm{C}$ were separated by SDS-PAGE with $12 \%$ acrylamide (Figure 4, $\operatorname{HinfI/C).~}$

HpaII also cleaved fragment $\mathrm{C}$ from Cux-1 DNA at three sites producing four different fragments of $228 \mathrm{bp}, 170 \mathrm{bp}, 148 \mathrm{bp}$ and $130 \mathrm{bp}$ (Figure 1b). The fragment $\mathrm{C}$ from all other isolates after digestion with HpaII also showed the same restriction profiles as Cux-1. SDS-PAGE with $12 \%$ acrylamide provided effective separation of the HpaII digested products of fragment C (Figure 4, HpaII/C). 


\section{Fragment D (552 bp)}

Fragment D was treated with the restriction endonuclease, EcoRI. The restriction map with EcoRI for fragment D is depicted in figure 1b. EcoRI cleaved the $552 \mathrm{bp}$ fragment D from Cux-1 DNA at only one site, producing two fragments, D1 (305 bp) and D2 (247 bp). Similar digestion pattern was found in 3-1 isolate. Whereas, all other isolates remained undigested exhibiting the original fragment indicating absence of EcoRI site. The DNA fragments generated after EcoRI digestion of fragment $\mathrm{D}$ were separated effectively by $2.5 \%$ agarose gel and displayed in figure 5 .

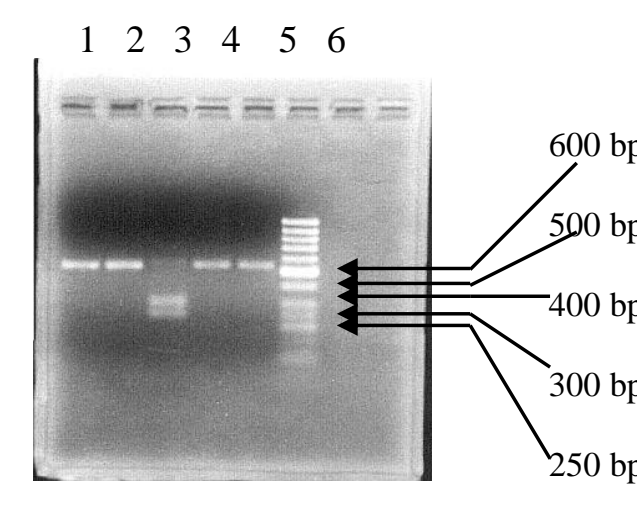

A

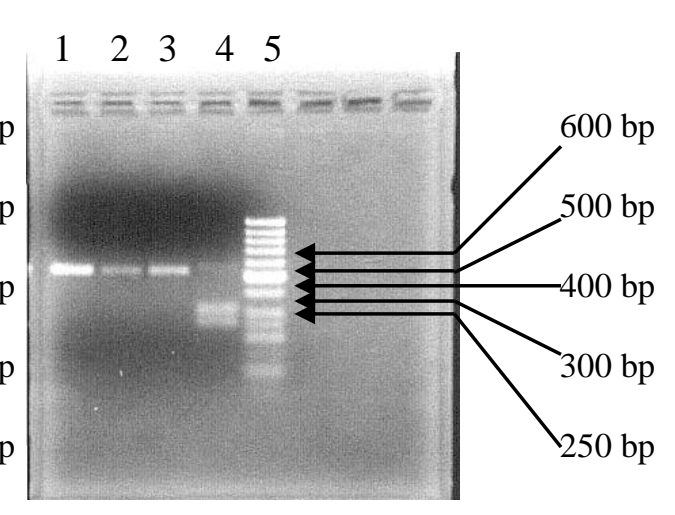

B

Figure 5: Restriction endonuclease (EcoRI) analysis of 552 bp fragment D amplified by PCR from DNAs specified by CAV isolates SMSC-1 (Lane 1), SMSC-2 (Lane 2), 3-1 (Lane 3), BL-1 (Lane 4), BL-2 (Lane 5) in A, and BL-3 (Lane 1), BL-4 (Lane 2), BL-5 (Lane 3), Cux-1 (Lane 4) in B. Lane 6 in A and Lane 5 in B indicate 50 bp DNA marker. Restriction fragments were separated by $2.5 \%$ agarose gel.

\section{DISCUSSION}

This is the first time that the whole CAV genomes of different CAV isolates were characterized by restriction endonuclease (RE) analysis. In this study, the PCR technology was first used to amplify different DNA fragments encompassing the whole CAV DNA. Then the enzymatic technology was applied with different restriction endonucleases to find out the molecular differences among the Malaysian local field isolates as well as a standard reference isolate $(\mathrm{Cux}-1)$ of CAV. Todd et al. (1992) differentiated 14 CAV isolates by RE analysis of PCR-amplified 675-bp fragment that encompasses the first half of the largest open reading frame (VP1). The present study, first time differentiated the Malaysian field CAV isolates as well as the European isolate, Cux-1, by RE analysis of four PCR-amplified DNA fragments encompassing the whole CAV genome. 
The primers selected for amplifying different fragments were based on Cux-1 sequence (Noteborn et al., 1991). These primers were specifically hybridized with the DNAs specified by Malaysian CAV isolates and effectively amplified the different DNA fragments from the CAV genomes with similar pattern as Cux-1 isolate. These procedures further confirm the Malaysian isolates as CAV, though these isolates have been confirmed earlier by other tests including PCR (Chowdhury et al., 2002).

The StyI digestion of fragment A and HpaII digestion of fragment B, each of which differentiated two isolates (SMSC-1 and BL-3) from other seven CAV isolates. The StyI digestion of fragment B separated five isolates (SMSC-2, BL-1, BL-2, BL-4 and BL-5) from other four isolates. The enzyme MboI differentiated SMSC-2 and 3-1 isolates from other seven isolates after digestion of fragment B. These two isolates also do not exhibit the same profiles, whereas the other seven isolates have the same MboI profiles. HaeIII digestion of fragment C distinguished two isolates (SMSC-1 and 3-1) from the other seven isolates, though these two isolates also do not have the same restriction profiles. In case of HinfI digestion of fragment $\mathrm{C}$ and EcoRI digestion of fragment $\mathrm{D}$, two isolates (3-1 and Cux-1) were differentiated in each case from the other seven isolates. The enzyme HpaII could not distinguish any of the nine isolates after digestion of fragment $\mathrm{C}$.

The results of restriction endonuclease analysis of different genome fragments revealed similar restriction profiles for four isolates (BL-1, BL-2, BL-4 and BL-5) in all enzymatic digestions (Table 1), indicating that these four isolates belong to one group and probably possess the same genomic characteristics. These isolates showed similar restriction profiles with Cux-1 isolate when digested by StyI (fragment A), HpaII, MboI and HaeIII, and were differentiated from Cux-1 isolate when the fragment B was digested by StyI.and fragment C was digested by HinfI.

SMSC-1 and BL-3 isolates always exhibited the same restriction profiles with different enzymatic digestions of different fragments, indicating maximum similarity between these two isolates (Table 1). However, only HaeIII digestion of fragment $\mathrm{C}$ differentiated SMSC-1 from BL-3, implying that these two are separate isolates (Table 1). These two isolates showed the same profiles as Cux-1 when digested with StyI (fragment B), MboI and HpaII (fragment C), but were different from Cux-1 when digested with StyI (fragment A), HpaII (fragment B), HinfI and EcoRI. SMSC1 isolate also could be differentiated from Cux-1 by HaeIII, while BL-3 isolate in this case, produced the same profile as Cux-1.

The SMSC-2 isolate showed the same restriction profiles as Cux-1 isolate by StyI (Fragment A), HpaI and HaeIII. This isolate was differentiated from Cux-1 by StyI (fragment B), MboI, and HinfI. The 3-1 isolate exhibited the same profiles with Cux1 in maximum enzymatic digestions, indicating highest similarity between these isolates. However, 3-1 isolate was differentiated from Cux-1 by MboI digestion of fragment $\mathrm{B}$ and HaeIII digestion of fragment C (Table 1). 
The results of restriction endonuclease analysis demonstrated that the isolates, SMSC-1, SMSC-2, 3-1, BL-3 and Cux-1 are different from each other and also from the group of the above four isolates (Table 1). The present study revealed that the restriction enzyme analysis differentiated CAV isolates, though obtained from the same poultry farm at the same time. The group of four isolates (BL-1, BL-2, BL-4 and BL-5) and the BL-3 isolate were isolated from same broiler farm. However, the restriction profiles differentiated $\mathrm{BL}-3$ from the group of four isolates, when digested by StyI (fragments A and B) and HpaII (fragment B). SMSC-1 and SMSC-2 isolates were also obtained from same broiler farm; these two isolates were found to be different from each other in five of the eight enzymatic digestions (Table 1).

The present findings and the findings of Todd et al. (1992) support the view that CAV isolates can be differentiated with number of restriction site differences occurring between isolates, though these isolates are antigenically and pathologically indistinguishable (McNulty et al., 1990; Connor et al., 1991; Yuasa and Imai, 1986). However, the findings of Todd et al. (1992) were confined with only 675 bp fragment of the CAV genome that is equivalent to fragment $\mathrm{C}$ of the present study. The three enzymes (HaeIII, HinfI and HpaII) used by them were also used in the present study for the fragment (675 bp/fragment C). Todd et al. (1992) made seven groups of CAV isolates based on the restriction site differences after restriction endonuclease analysis (with HaeIII, HinfI and HpaII) of the 675 bp fragment from 14 CAV isolates derived from seven different countries (UK, Ireland, Germany, Sweden, USA, Japan and Australia). When compared with the CAV groupings made by Todd et al. (1992), the present findings with three enzymatic digestions (with HaeIII, HinfI and HpaII) of the $675 \mathrm{bp}$ fragment (fragment $\mathrm{C}$ ) provided the following groupings for the isolates of the present study. SMSC-1 fell in group 7 to which placed Australian IMP 704 isolate (Todd et al., 1992). SMSC-2, BL-1, BL-2, BL-3, BL-4 and BL-5 isolates fell in group 2 which placed Japanese TK 5803, Sweden 1/80 and 1/91 isolates (Todd et al., 1992). Cux-1 isolate fell in group 1, which substantiated the finding of Todd et al., (1992), where also placed Japanese Gifu-1 isolate. Only 3-1 isolate of the present study did not fall in any of the group made by Todd et al. (1992) and for this isolate we are creating a new group, i.e. group 8 in addition to the groups made by Todd et al. (1992). CAVs were also differentiated by RE analysis of single genome fragments by other investigators (Nayabian and Mardani, 2013; Oluwayelu et al., 2005; van Santen et al., 2001).

In the present study, different PCR-amplified genome fragments covering the whole CAV genome, after digestion with different restriction enzymes, differentiated more isolates than the single genome fragment digested by the three enzymes (HaeIII, HinfI and HpaII). Therefore, restriction endonuclease analysis with different fragments of the genome under the present study gave proper genomic diversity than that with the single genome fragment dealt with by Todd et al. (1992).

Different restriction endonucleases recognise only small portion of sequences from the whole genome. Based on this, it is difficult to assess the actual sequence diversity 
between CAV isolates. Therefore, it is better to perform sequencing to determine the actual sequence diversity. However, detection of sequence for epidemiological purposes only may not be practical for many diagnostic laboratories, since sequence analysis is expensive and needs sophisticated and costly equipments. Instead, restriction endonuclease analysis may be at least an alternative method to detect molecular differences.

\section{CONCLUSION}

The study revealed that restriction endonuclease analysis could be used to identify and differentiate CAV isolates based on the number of restriction site differences, though these isolates are antigenically indistinguishable. Restriction endonuclease analysis of different genome fragments could also be used to differentiate isolates obtained from the same poultry farm. The analysis showed that more isolates could be distinguished with proper genomic diversity after restriction endonuclease analysis of more genome fragments compared to that of single genome fragment. The first time present findings may be most useful for epidemiological purposes.

\section{ACKNOWLEDGEMENT}

This work was supported by IRPA grant no. 01-02-04-T002, Ministry of Science, Technology and Environment, Malaysia.

\section{REFERENCES}

AboElkhair, M., Abd, A.G., and Metwally, A.E.Y. (2014). Molecular characterization of chicken anemia virus circulating in chicken flocks in Egypt. Advances in Virology, 2014, ID 797151, 6 pages. http://dx.doi.org/10.1155/2014/797151.

Adair, B.M. (2000). Immunopathogenesis of chicken anemia virus infection. Developmental \& Comparative Immunology, 24 (2-3), 247-255.

Breitbart, M. (2015). Move Genus Gyrovirus from the family Circo viridae to the family Anelloviridae. ICTV taxonomy history for chicken anemia virus, London UK (2015).

Bülow, V.V., Fuchs, B., Vielitz, E., and Landgraf, H. (1983). Frühsterblichkeitssyndrom bei Küken nach infektion mit dem Virus der Marekschen Krankheit (MDV) und einem Anämie-Erreger (CAA) (Early mortality syndrome of chickens after dual infection with Marek's disease virus (MDV) and chicken anaemia agent (CAA)). Zentralbl Veterinärmed, B 30, 742-750.

Chowdhury, S.M.Z.H., Omar, A.R., Aini, I., Hair-Bejo, M., Jamaluddin, A.A., Kono, Y., Darus, A., and Yatim, H.M. (2002). Isolation, identification and characterization of chicken anemia virus in Malaysia. Journal of Biochemistry, Molecular Biology and Biophysics, 6 (4), 249-255.

Connor, T.J., McNeilly, F., Firth, G.A., and McNulty, M.S. (1991). Biological characterization of Australian isolates of chicken anaemia agent. Australian Veterinary Journal, 68, 199-201. 
Coombes, A.L., and Crawford, G.R. (1996). Chicken anaemia virus: a short review. World's Poultry Science Journal, 52, 267-277.

De Herdt, P., Van den Bosch, G., Ducatelle, R., Uyttebroek, E., and Schrier, C. (2001). Epidemiology and significance of chicken infectious anemia virus infections in broilers and broiler parents under nonvaccinated European circumstances. Avian Diseases, 45, 706-708.

Engstrom, B.E., and Luthman, M. (1984). Blue wing disease of chickens: signs, pathology and natural transmission. Avian Pathology, 13, 1-12.

Farkas, T., Maeda, K., Sugiura, H., Kai, K., Hirai, K., Otsuki, K., and Hayashi, T. (1998). A serological survey of chickens, Japanese quail, pigeons, ducks and crows for antibodies to chicken anaemia virus (CAV) in Japan. Avian Pathology, 27 (3), 316-320.

Ganar, K., Shah, M., Kamdi, B.P., Kurkure, N.V., and Kumar, S. (2017). Molecular characterization of chicken anemia virus outbreaks in Nagpur province, India from 2012 to 2015. Microbial Pathogenesis, 102, 113-119.

Ledesma, N., Fehervari, A.T., Casaubon, M.T., Lucio, E., and Ratz, F. (2001). Chicken infectious anemia in Mexico: virus identification and serology survey. Avian Diseases, 45, 788-796.

Li, Y.P., and Cui, Z.Z. (2007). Pathogenicity and genomic sequence comparison of a chicken infectious anemia virus field isolate. Wei Sheng Wи Хие Bao, 47(5), 894-8. [Article in Chinese]

McNulty, M.S. (1991). Chicken anemia agent: a review. Avian Pathology, 20, 187-203.

McNulty, M.S., Connor, T.J., McNeilly, F., McLoughlin, M.F., and Kirkpatrick, K.S. (1990). Preliminary characterization of isolates of chicken anaemia agent from the United Kingdom. Avian Pathology, 19, 67-73.

Nayabian, H., and Mardani, K. (2013). Molecular characterization of the chicken anaemia viruses isolated from broiler farms of west Azerbaijan, Iran. Avian Pathology, 42 (2), 108-113.

Noteborn, M.H.M., De Boer, G.F., van Roozelaar, D.J., Karreman, C., Kranenburg, O., Vos, J.G., Jeurissen, S.H.M., Hoeben, R.C., Zantema, A., Koch, G., van Ormondt, H., and van der Eb, A.J. (1991). Characterization of cloned chicken anemia virus DNA that contains all elements for the infectious replication cycle. Journal of Virology, 65, 3131-3139.

Noteborn, M.H.M., Verschueren, C.A.J., van Roozelaar, D.J., Veldkamp, S., van der Eb, A.J., and de Boer, G.F. (1992). Detection of chicken anaemia virus by DNA hybridisation and polymerase chain reaction. Avian Pathology, 21, 107-118.

Olszewska-Tomczyk, M., Swieton, E., Minta, Z., and Smietanka, K. (2016). Occurrence and phylogenetic studies of chicken anemia virus from polish broiler flocks. Avian Diseases, 60, 70-74.

Oluwayelu, D.O., Todd, D., Ball, N.W., Scott, A.N., Oladele, O.A., Emikpe, B.O., Fagbohun, O.A., Owoade, A.A., and Olaleye, O.D. (2005). Isolation and preliminary characterization of chicken anemia virus from chickens in Nigeria. Avian Diseases, 49(3), 446-50. 
Pope, C.R. (1991). Chicken anaemia agent. Veterinary Immunology and Immunopathology, 30, 51-65.

Rehman, L.U., Sultan, B., Ali, I., Bhatti, M.A., Khan, S.U., Zaman, K.U., Jahangiri, A.T., Khan, N.U., Iqbal, A., Bakht, J., Swati, Z.A., and Rehman, M.U. (2011). Duplex PCR assay for the detection of avian adeno virus and chicken anemia virus prevalent in Pakistan. Virology Journal, 8, 440, doi: 10.1186/1743-422X-8-440.

Rosenberger, J.K., and Cloud, S.S. (1989). The effects of age, route of exposure, and coinfection with infectious bursal disease virus on the pathogenicity and transmissibility of chicken anaemia agent (CAA). Avian Diseases, 33, 753-759.

Schat, K.A. (2003). Chicken infectious anemia. In: Saif, Y.M., Barnes, H.J., Glisson, J.R., Fadly, A.M., McDougald, L.R., Swayne, E., eds. Diseases of Poultry. $11^{\text {th }}$ ed. Ames, Iowa, USA: Iowa State University Press; 2003. p. 182-202.

Soiné, C., Watson, S.K., Rybicki, E., Lucio, B., Nordgren, R.M., Parrish, C.R., and Schat, K.A. (1993). Determination of the detection limit of the ploymerase chain reaction for chicken anaemia virus. Avian Diseases, 37, 467-476.

Spackman, E., Cloud, S.S., Pope, C.R., and Rosenberger, J.K. (2002a). Comparison of a putative second serotype of chicken infectious anemia virus with a prototypical isolate I. Pathogenesis. Avian Diseases, 46, 945-955.

Spackman, E., Cloud, S.S., and Rosenberger, J.K. (2002b). Comparison of a putative second serotype of chicken infectious anemia virus with a prototypical isolate II. Antigenic and physicochemical characteristics. Avian Diseases, 46, 956-963.

Stanislawek, W.L., and Howell, J. (1994). Isolation of chicken anaemia virus from broiler chickens in New Zealand. New Zealand Veterinary Journal, 42 (2), 58-62.

Tham, K.M., and Stanislawek, W.L. (1992). Detection of Chicken anaemia DNA sequences by the polymerase chain reaction. Archives of Virology, 127, 245-255.

Todd, D., Mawhinney, K.A., and McNulty, M.S. (1992). Detection and differentiation of chicken anaemia virus isolates by using polymerase chain reaction. Journal of Clinical Microbiolgy, 30, 1661-1666.

Todd, D., Creelan, J.L., Meehan, B.M., and McNulty, M.S. (1996). Investigation of the transfection capability of cloned tandemly-repeated chicken anaemia virus DNA fragments. Archives of Virology, 141, 1523-1534.

Van Santen, V.L., Li, L., Hoerr, F.J., and Lauerman, L.H. (2001). Genetic characterization of chicken anemia virus from commercial broiler chickens in Alabama. Avian Diseases, 45 (2), 373-88.

Yuasa, N., and Imai, K. (1986). Pathogenicity and antigenicity of eleven isolates of chicken anemia agent (CAA). Avian Pathology, 15, 639-645.

Zhang, X., Xie, Q., Ji, J., Chang, S., Liu, J., Chen, F., Ma, J., and Bee, Y. (2012). Complete genome sequence analysis of a recent chicken anemia virus isolate and comparison with a chicken anemia virus isolate from human fecal samples in China. Journal of Virology, 86 (19), 10896-7, doi: 10.1128/JVI.01749-12.

Zhou, W., Yang, B., Shen, B., Han, S., and Zhou, J. (1996). A serologic survey of antibody against chicken infectious anemia virus by indirect immunofluorescent assay in domestic poultry in China. Avian Diseases, 40, 358-360. 